\title{
Debris flow occurrences in Rio dos Cedros, Southern Brazil: meteorological and geomorphic aspects
}

\author{
M. Kobiyama, R. F. Goerl, G. P. Corrêa \& G. P. Michel \\ Laboratory of Hydrology, Federal University of Santa Catarina, Brazil
}

\begin{abstract}
In Santa Catarina State (Brazil), Rio dos Cedros is one of the cities that suffered from natural disasters triggered by very intense rainfall in November 2008 . According to the Municipal Civil Defense, this event caused economic losses of US\$2.1 million and 96 homeless, directly affecting $90 \%$ of the municipal population. The principal phenomenon responsible for these disasters was the debris flow. In this context, field surveys were conducted throughout the city in order to investigate the possibility for houses to be affected by landslides and debris flows. After the preliminary evaluation, two cases of debris flow whose extensions were over $1 \mathrm{~km}$ were chosen for a more detailed survey. The objective of the present study was to analyze the meteorological and geomorphic aspects of these cases. The total rainfall in Rio dos Cedros in November 2008 and the entire year of 2008 were $644 \mathrm{~mm}$ and $2509 \mathrm{~mm}$, respectively. An analysis of the daily rainfall during October and November 2008 and the debris flow occurrence time indicates that the factor triggering debris flows in Rio dos Cedros in 2008 was the accumulated rainfall, not its intensity. Two debris flows analyzed in the present study had different geomorphic conditions, one being confined in the channel and showing ordinal debris flow (Debris A), and the other unconfined, presenting the debris avalanche feature (Debris B). The larger density of clastic blocks was observed at the depositional area of Debris B. Both the localities are characterized with migmatite. Topographic analysis showed that the volume of the mass movement is related with topographic parameters (elevation difference and travel distance). This relationship implies that the two cases of Rio dos Cedros had similar behavior to other cases reported in temperate and cold regions. It is, therefore, concluded that there is geomorphic control on
\end{abstract}


the debris flow behavior. The similarity of Debris A and B implies the high potential effects of woody vegetation on the debris flow feature.

Keywords: debris flow, volume of mass movement, topographic survey, rainfall, woody vegetation, Brazil.

\section{Introduction}

By elaborating an atlas of natural disasters of Santa Catarina State (SC), Brazil, Herrmann [6] shows that SC has frequently suffered from hydrological disasters. In November 2008, the extremely intense rainfall event triggered floods and landslides in SC, especially in the Itajaí Valley. This event might be the worst in the whole history of SC. Rocha et al. [9] analyzed the daily rainfall data obtained in Blumenau city, which is located in the Itajaí Valley, and concluded that the daily rainfall of $347.2 \mathrm{~mm}$ registered on $23^{\text {rd }}$ November corresponds to a return period of more than 10,000 years for this city. Among 293 cities in SC, 63 declared a state of emergency and 14 a state of public calamity in November 2008. According to the State Civil Defense Report 31/Dec/2008, which presented the total damages caused by these disasters, there were 32,853 homeless, 135 dead and 2 missing in SC.

In the hydrological and socio-economic aspects, the Itajaí Valley is one of the most important regions in SC and consists of 53 cities. According to Fraga [3] and Frank and Pinheiro [4], the floods in this valley have been registered for more than 150 years. Up to now, the historically large floods in the Itajaí Valley occurred in 1855, 1880, 1911, 1927, 1957, 1983, 1984, 1992 and 2008.

Rio dos Cedros, city located in the Itajaí Valley, at a distance from Blumenau about $30 \mathrm{~km}$, declared a state of pubic calamity due to the intense rainfall in November 2008. It was reported that 8,561 peoples were directly affected, 96 homeless, no dead, and economic losses of agriculture, livestock, industry and basic sanitation infra-structures in the range of US\$1.34 million, 300 thousands, 40 thousands, and 390 thousands, respectively. The floods occurred in the urban area and the typical landslide type that occurred in many rural ones was the debris flow in this city.

Though the frequency of its occurrence has increased recently, there are only a few studies on the debris flow in Brazil until now. The debris flow research can be, therefore, considered as one of the priorities in the Brazilian society. In this context, the objective of the present study was to analyze the meteorological and geomorphic aspects of two debris flow features which occurred in Rio dos Cedros city in November 2008.

\section{Methods}

\subsection{Study area}

In Rio dos Cedros city, the population and the area are 9,685 and $556 \mathrm{~km}^{2}$, respectively. Most of the inhabitants live in the urban area $\left(18 \mathrm{~km}^{2}\right)$ located on 


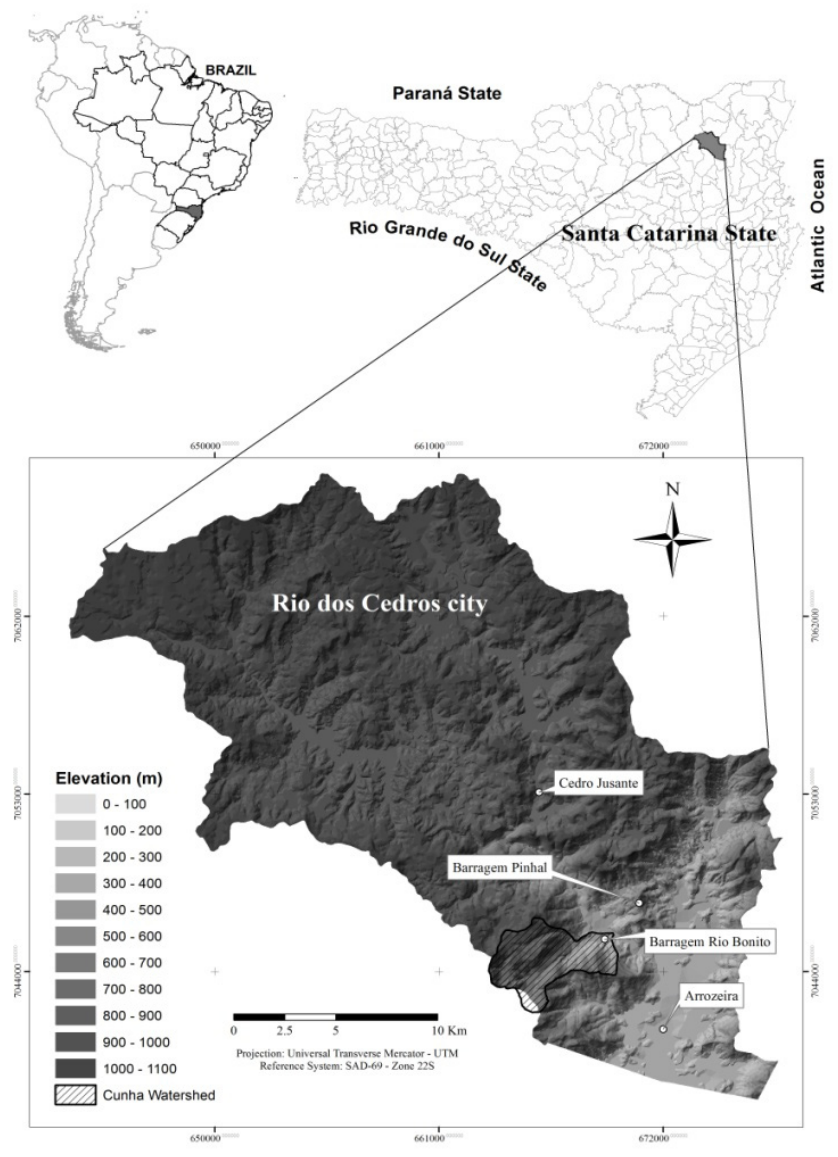

Figure 1: Localities of Rio dos Cedros city, Cunha watershed and rain gauge stations.

the floodplain. Thus, the floods have frequently affected human lives. The highland is used for agriculture, reforestation and hydro-energy generation. There are two dams (Palmeiras and Pinhal) in this city. As the administration boundary of the city coincides almost with the Cedro River watershed divide, the watershed management may be highly useful for the city hall (Figure 1). There are topographic maps only at a $1 / 50.000$ scale for the study area.

The relief of Rio dos Cedros city can be divided into three zones: (i) the law lands formed by floodplain and by small hills with altitude from 75 to $150 \mathrm{~m}$ and gentle slopes $\left(\sim 12^{\circ}\right)$; (ii) the highlands with altitude from 600 to $1100 \mathrm{~m}$ and gentle slopes in most of the areas $\left(\sim 16^{\circ}\right)$; and (iii) the transition zone between the two former lands, with steep slopes and embedded valleys. In this transition zone the major landslides occurred. Goerl et al. [5] reported 15 severe landslides triggered by the intense rainfall in this city in November 2008. Their main type was the debris flow, and most of them occurred on steep slopes with colluvium 
deposits on their base. From this evidence the authors [5] concluded that landslides are very frequent and natural phenomena in the geological and geomorphologic time scale. The fact that there are a lot of big blocks along the main channels in the watershed, especially in the zones (ii) and (iii), implies the high susceptibility to the debris flows in these two zones.

\subsection{Meteorological data}

To analyze the rainfall characteristics in Rio dos Cedros, the present study used the monthly data obtained at the rain gauge station (Arrozeira) of the National Agency of Water - ANA from 1942 to 2006 and the hourly data from 2007 to 2008 recorded at three rain gauge stations (Barragem Pinhal, Barragem Rio Bonito, Cedro Jusante) of the Company of Agricultural Research and Rural Extension of Santa Catarina - EPAGRI. Their localities are shown in Figure 1.

\subsection{Field survey}

In the Cunha River watershed, two comparatively-larger debris flows were investigated. Figure 2 shows the digital elevation model of this watershed and two debris flows which are here called Debris A and Debris B. It also presents Debris A (1 and 2) and Debris B (1 and 2) in detail.

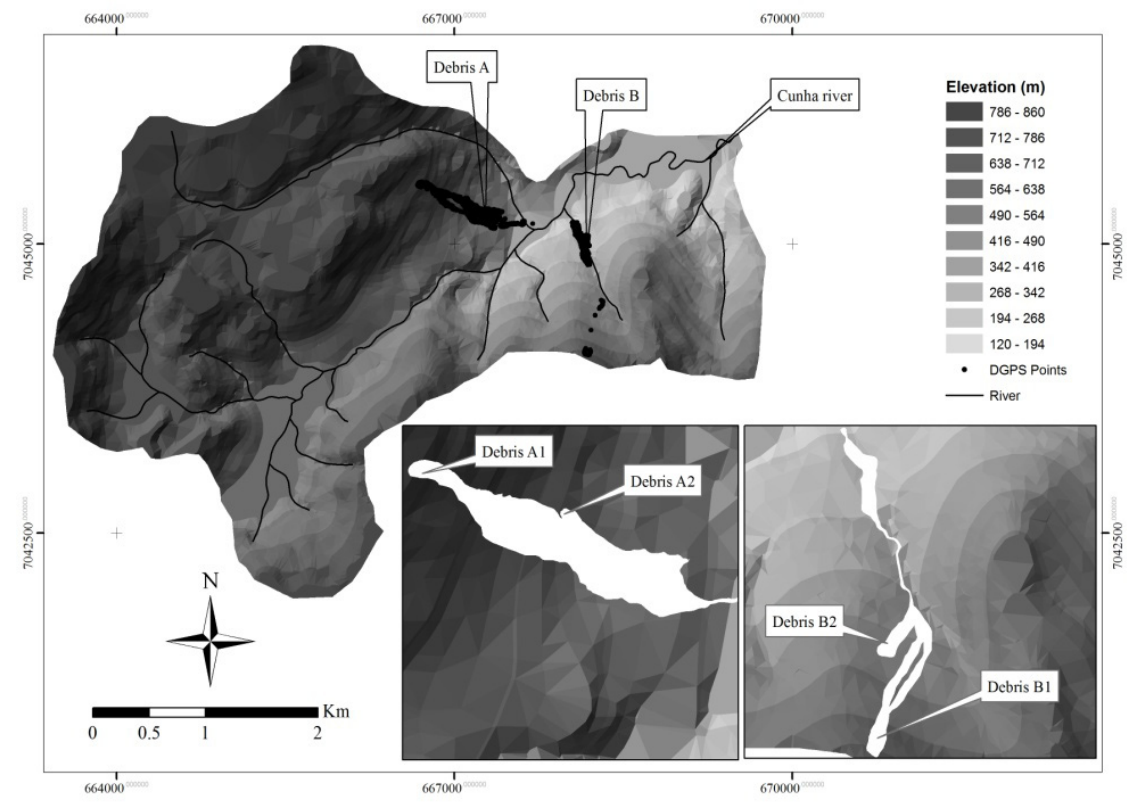

Figure 2: Localities of two debris flows (Debris A and Debris B) in the Cunha river watershed. 
The field survey with the Leica Total Station and the Trimble Differential GPS (DGPS) was carried out during September 2009, about 10 months after the occurrence, because it was necessary to wait for the complete stabilization of the hillslopes. The DGPS was used to collect several points around and in the middle of the debris flow for determining the geometric relationship and for calculating the mass movement volume and the depositional volume. When it was not possible to collect data with the DGPS, the Total Station was used.

All the points were put into the same projection and reference system: UTM Zone 22S and SAD-69. More than 3000 points were collected with an altimetric error less than $0.5 \mathrm{~m}$. For each debris flow, the survey focused on three parts: (i) starting; (ii) channel transporting; and (iii) depositional area.

\subsection{Debris flow volume analysis}

Based on the field observations, the rupture surface of the landslide starting areas was considered as an ellipsoid. This geometric assumption easily permitted to calculate the volume of mass movement. By processing the DGPS point in the ArcGIS software, the geometric relationships were established for each debris flow. The starting area, the spread channel area and the depositional area were delimitated with the reach angle and the field observations. Both the cases (Debris A and Debris B) had two different staring areas, i.e., two initial movements. In other words, four landslides occurred and formed two large debris flows. For a better presentation of the real forms, each landslide was calculated individually. Then, the Debris A (or Debris B) was divided into Debris A1 and A2 (or Debris B1 and B2).

For each starting area, the altimetry difference between the higher and lower point $(H s)$ and the axial distances $\left(l_{s}\right)$ were calculated, and then $\tan \theta(=H s / l s)$ was determined. The rupture area of the movement follows an ellipse plane, passing through the hypotenuse vertex. Thus, the mass movement height (hsi) is considered equal to half of the median, and the hypotenuse is the length of the $\mathrm{Y}$ plane. Figure 3 illustrates the definition of the geometry used in this calculation.

Then, the total volume of the mass movement for each debris flow can be expressed by the following eqn:

$$
V_{\text {Debris }}=V_{\text {debris } 1}+V_{\text {debris } 2}=\frac{\frac{4}{3} \pi a_{1} b_{1} c_{1}}{2}+\frac{\frac{4}{3} \pi a_{2} b_{2} c_{2}}{2}
$$

where $V_{\text {Debris }}$ is the total volume of the mass movement of the Debris A or B; $V_{\text {debris } 1}$ and $V_{\text {debris } 2}$ are the volume of the two initial movements; $a_{1}$ and $a_{2}$ are the positive numbers which represent the X-dimension of the two ellipsoids; $b_{1}$ and $b_{2}$ are the positive numbers which represent the Y-dimension of the two ellipsoids; $c_{1}$ and $c_{2}$ are the positive numbers which represent the Z-dimension of the two ellipsoids.

Corominas [2] and Rickenmann [7] separately proposed an equation that relates the volume of movement mass $(V)$ with the angle of reach $(\beta)$ in which $\tan \beta=H / L$ : 
82 Monitoring, Simulation, Prevention and Remediation of Dense and Debris Flows III

$$
\begin{gathered}
V_{C}=\left(\frac{L}{1.03 H}\right)^{\frac{1}{0.105}} \\
V_{R}=\left(\frac{L}{1.90 H^{0.83}}\right)^{\frac{1}{0.160}}
\end{gathered}
$$

where $V_{C}$ and $V_{R}$ are the volumes in $\mathrm{m}^{3}$ estimated by Corominas [2] and Rickenmann [7], respectively; $H$ is the elevation difference between starting point and the lowest point of the depositional area in meter; and $L$ is the travel distance in meter. Corominas [2] analyzed the topography of 71 debris flows reported in several countries and made a linear regression. Rickenmann [7] elaborated the same relation by using the data of 140 debris flows and 51 rock avalanches recorded in Swiss Alps.

Analogically, the total volumes of the mass movement calculated by Corominas [2] and Rickenmann [7] equations can be expressed:

$$
\begin{gathered}
V_{C}=\left(\frac{L_{1}}{1.03 H_{1}}\right)^{\frac{1}{0.105}}+\left(\frac{L_{2}}{1.03 H_{2}}\right)^{\frac{1}{0.105}} \\
V_{R}=\left(\frac{L_{1}}{1.90 H_{1}^{0.83}}\right)^{\frac{1}{0.160}}+\left(\frac{L_{2}}{1.90 H_{2}^{0.83}}\right)^{\frac{1}{0.160}}
\end{gathered}
$$

Floorplan Sectional Plan
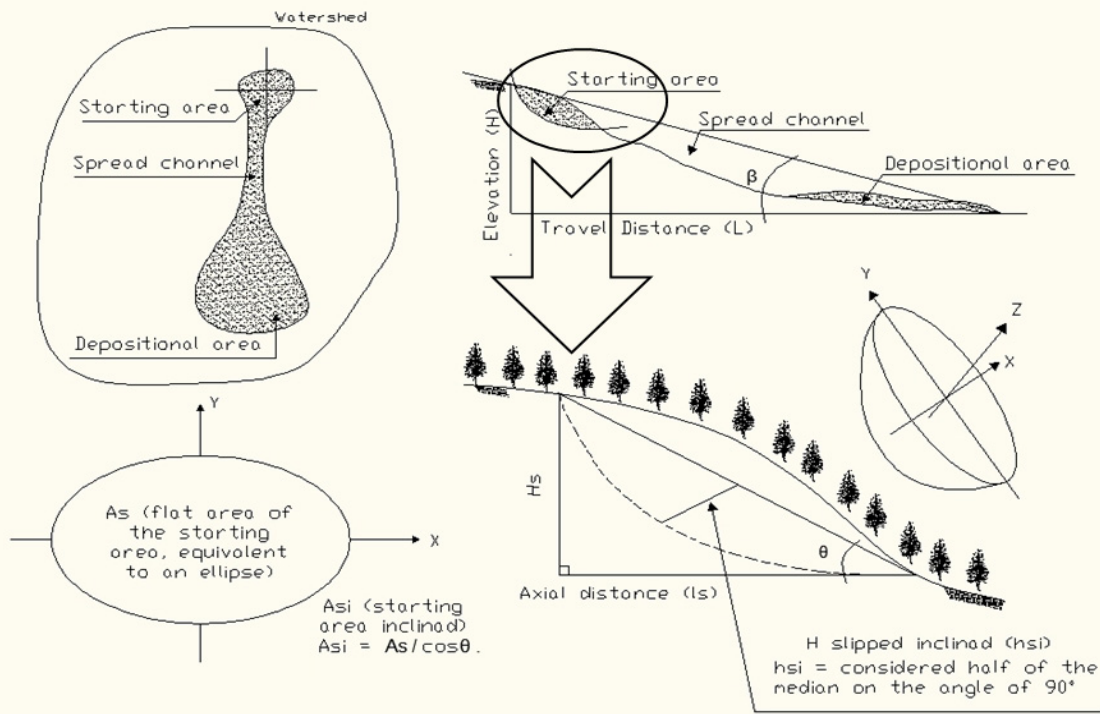

Figure 3: Geometry of debris flow. 
The volume estimated with eqn (1) was compared to those obtained with eqns (4) and (5).

\section{Results and discussions}

\subsection{Rainfall analysis}

Figure 4 shows the historical data of the annual rainfall from 1942 to 2008 . It can be observed a slight increase of the annual rainfall during the studied period, with its mean value of $1651 \mathrm{~mm} /$ year. The highest value was $2863 \mathrm{~mm} /$ year in 1983; meanwhile 2008 was the second rainiest year with $2509 \mathrm{~mm} /$ year.

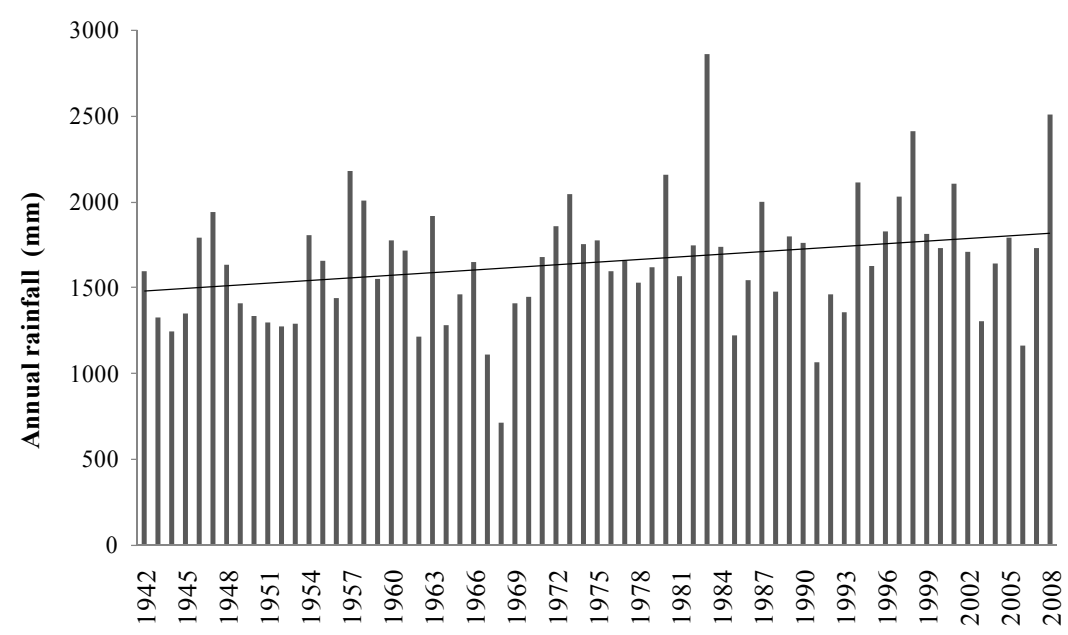

Figure 4: $\quad$ Annual rainfall in Rio dos Cedros during the period 1942 to 2008.

The total rainfall of October and November 2008 was $1085 \mathrm{~mm}$ which represented about $43.3 \%$ of the 2008 annual rainfall. On $3^{\text {rd }}$ October, the most intense rainfall (122 $\mathrm{mm} /$ day) was recorded, and after this event no high rainfall intensity took place. In November, the values of the daily rainfall were not very high (less than $80 \mathrm{~mm} /$ day), but their frequency was much higher than in October and the accumulated rainfall was very high (Figure 5).

According to Mr. Rui Mayer (local resident), the mass movement took place on three stages, the first at 1:15 a.m., the second at 2:00 a.m. and the third at 3:00 on $24^{\text {th }}$ November. The observed rainfall data in Rio dos Cedros showed that during the period from 0:00 a.m. to 3:00 a.m. on the same day, it rained $10 \mathrm{~mm}$ which might not be able to cause such a terrible and intense phenomenon. The accumulated rainfall from 0:00 a.m. on $23^{\text {rd }}$ November to 3:00 a.m. on $24^{\text {th }}$ November was $95 \mathrm{~mm}$. Only for one week from $18^{\text {th }}$ to $24^{\text {th }}$ November, it rained totally $256 \mathrm{~mm}$, more than twice value of the mean monthly rainfall for November. In October and November 2008, the highest values of monthly rainfall during the period 1942 to 2008 were recorded with $441 \mathrm{~mm}$ and $644 \mathrm{~mm}$, 


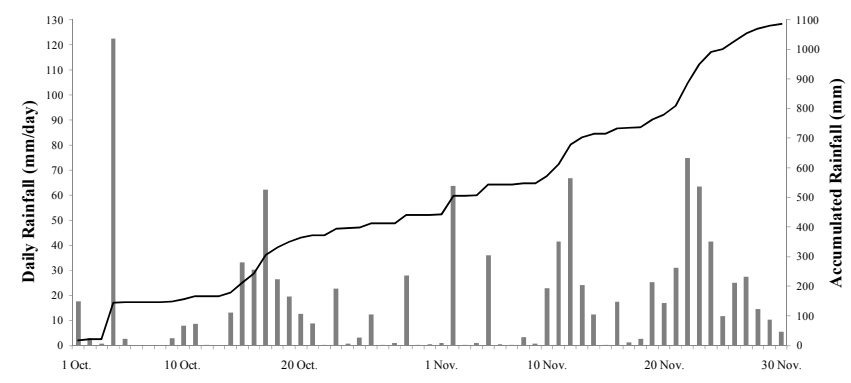

Figure 5: Daily and accumulated rainfalls in Rio dos Cedros from October to November 2008.

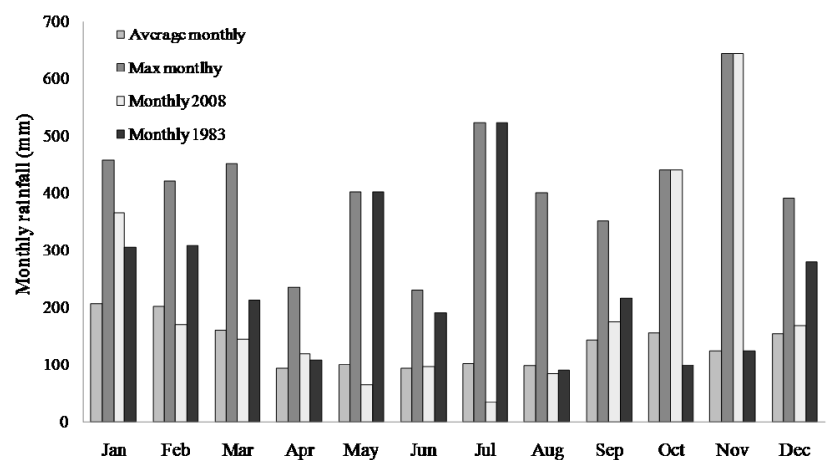

Figure 6: Monthly rainfall data from Rio dos Cedros: mean monthly rainfall from 1942 to 2007, maximum monthly record between 1942 and 2008, monthly rainfall of 2008, and monthly rainfall of 1983 .

respectively (Figure 6). The monthly rainfall in November 2008 was highest during the period 1942-2008. Therefore it may be said that in this case the triggering factor was the accumulated value of the rainfall, not its intensity.

Mr. Genésio Zoboli (local resident) informed that the water of the stream where debris flow (Debris B) passed had already possessed a high turbidity since September 2008 and that in 1974 a debris flow with smaller scale and intensity occurred at the same place. It indicates that the locality of the Debris B has the high vulnerability to the debris flow.

\subsection{Geomorphic analysis}

From the initial movement of higher altitude, the total distance of Debris A was $1050 \mathrm{~m}$, while Debris B reached $1270 \mathrm{~m}$. Both debris flows occurred at the same rock type (migmatite). Table 1 shows the calculation results with eqns (1), (4) and (5) that present the geometric analysis, Corominas [2] and Rickenmann [7] relationships, respectively. It can be noted that, in both the cases $\mathrm{A}$ and $\mathrm{B}$, the equation of Corominas [2] presented the highest value, while Rickenmann [7] 
Table 1: $\quad$ Calculation results of different methods.

\begin{tabular}{|c|c|c|c|c|c|c|c|}
\hline & & $\begin{array}{c}\text { Calculated } \\
\text { eqn (1) }\end{array}$ & $\begin{array}{c}\text { Corominas } \\
\text { eqn }(4)\end{array}$ & $\begin{array}{c}\text { Rickenmann } \\
\text { eqn (5) }\end{array}$ & \multirow[t]{2}{*}{ Weighted } & \multirow[t]{2}{*}{$\tan \theta$} & \multirow[t]{2}{*}{$\tan \beta$} \\
\hline & & \multicolumn{3}{|c|}{ Volume $\left(\mathrm{m}^{3}\right)$} & & & \\
\hline & DebrisA1 & $49,794.77$ & $19,952.92$ & $7,458.11$ & 89.05 & 0.34 & - \\
\hline & DebrisA2 & $6,120.69$ & $935,236.77$ & $35,521.16$ & 10.95 & 0.23 & - \\
\hline Debris & Total & $55,915.46$ & $955,189.69$ & $42,979.27$ & 100.00 & - & 0.33 \\
\hline \multirow[t]{4}{*}{ A } & Difference* & - & $899,274.23$ & $12,936.19$ & - & - & - \\
\hline & Difference $(\%)$ & - & $1,608.27$ & 23.14 & - & - & - \\
\hline & DebrisB1 & $26,135.71$ & $12,702.70$ & $7,071.48$ & 42.61 & 0.36 & - \\
\hline & DebrisB2 & $35,201.03$ & $62,534.86$ & $12,002.17$ & 57.39 & 0.30 & - \\
\hline Debris & Total & $61,336.74$ & $75,237.56$ & $19,073.65$ & 100.00 & - & 0.33 \\
\hline \multirow[t]{2}{*}{ B } & Difference* & - & $13,900.82$ & $42,263.09$ & - & - & - \\
\hline & Difference $(\%)$ & - & 22.66 & 68.90 & - & - & - \\
\hline
\end{tabular}

$*$ Difference between eqn (1) and eqn (4) (or eqn (5)).

the lowest. For the Debris A, the value obtained with the equation of Corominas [2] (eqn (4)) was closer to the value obtained with the topography survey, while in Debris B Rickenmann [7] (eqn (5)) was closer.

Since each debris flow had two starting areas (initial movements) (Figure 2), their weights were calculated. In the Debris A, the movement A1 had the more importance for the total volume and consequently the more contribution to the total travel distance of the debris flow. In the Debris B, both the initial movements had similar weights and volumes, contributing equally to the magnitude of the debris flow occurrence.

Figure 7 plots the values of the Debris A and B obtained with eqn (1) on the diagram originally elaborated by Rickenmann [8] which relates $\tan \beta$ with the mass movement volume. In the tropical environments, the soil layer tends to become larger than that in the temperate regions. In both the cases of the present study, the average of the soil layer depth was $15 \mathrm{~m}$. And the soil texture was characterized with large quantity of silt and clay. Furthermore there was a lot of vegetation on the occurrence localities, especially trunks with 20-30 m height, which might characterize the woody debris flows. In spite of these conditions, it is observed that two cases of Rio dos Cedros had the similar behavior to other cases shown by Rickenmann [8], especially to Swiss debris flows.

Though Figure 7 shows that the Debris A and B had a similar behavior, the geomorphic conditions are different between the Debris A and B. The Debris A is characterized as a debris avalanche, not channeled or constrained, meanwhile the Debris B is mostly confined and received a strong topographic control.

Rickenmann [8] mentioned that the angle of initial depositional process varies between 6 and $12^{\circ}$ for many (larger) debris flows and can be larger than $27^{\circ}$ for smaller and unconfined cases. Slaymaker [10] and Bryant [1] assumed that the depositional angle is smaller than $12^{\circ}$. The depositional angle values of the Debris $\mathrm{A}$ and $\mathrm{B}$ were $13^{\circ}$ and $14^{\circ}$, respectively. The similar characteristics between the Debris A and B were the large depositional-angle, the starting slope, the depth (approximately $8-10 \mathrm{~m}$ ) of deposition layer. The factor that controls the 


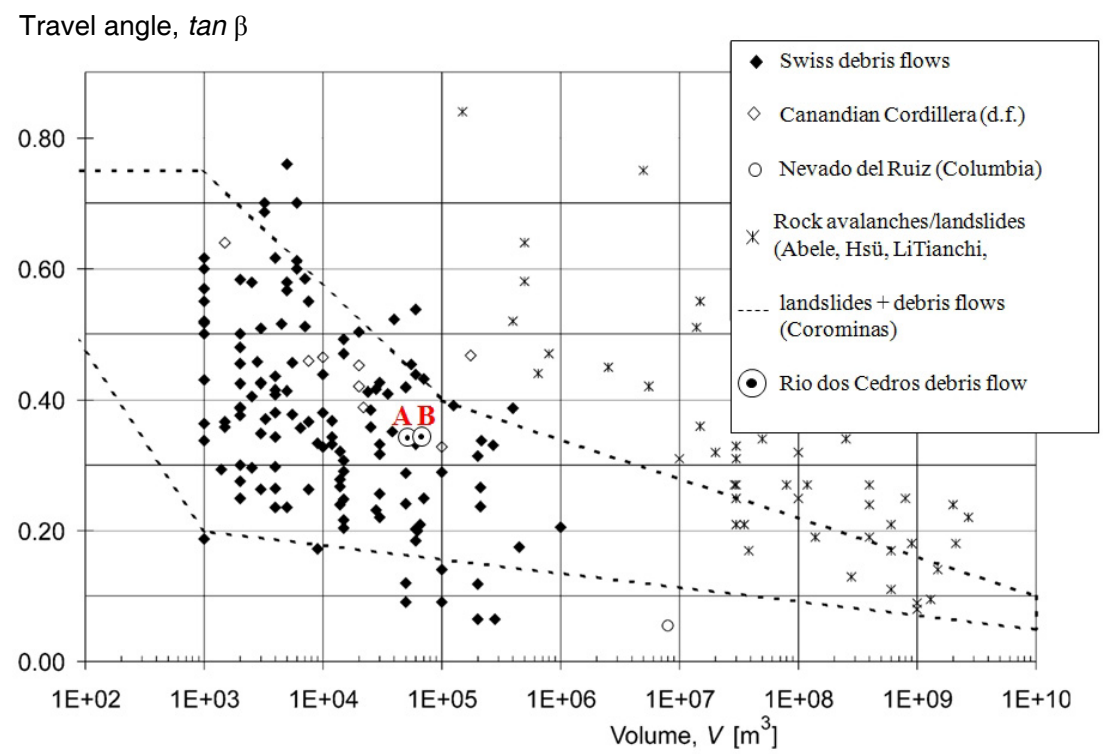

Figure 7: Travel angle vs. volume of mass movement including Rio dos Cedros debris flows A and B (modified from Rickenmann [8]).

movement and generates the similar behavior may be the high density of the woody vegetation lying on the occurrence localities. In the Debris B, the vegetation provided the dams (barriers) formation, reducing the energy gradient. But when the dam break takes place, the potential energy might be equal to the total energy and the destructive power of the debris flow was elevated. According to the residents' testimony, the movement occurrence with various waves was observed and bursts were heard.

Thus, the relationship between the mass movement volume and the travel angle (geomorphic factor) obtained in the present study is coherent to those observed in other countries. Therefore, it can be said that the geomorphic control of the debris flow is very important. But the similarity between the two debris flows which had different geomorphic conditions implies that the woody vegetation effect on the debris flow is potentially very significant.

\section{Conclusions}

The extremely-intense rainfall triggered the hydrological disasters in Rio dos Cedros city in November 2008. The typical disaster type was the debris flow. The present study analyzed the rainfall characteristics in this city for the period 1942 to 2008, with the special attention to the rainfall events of 2008. In October and November 2008, the monthly rainfalls were $441 \mathrm{~mm}$ and $643.6 \mathrm{~mm}$, respectively. An analysis of the daily rainfall during these two months and the debris flow occurrence time indicates that the triggering factor in the case of debris flows in 2008 was the accumulated rainfall, not its intensity. 
Based on the previous investigation, two large debris flow cases (Debris A and Debris B) were selected for the geomorphic analysis. With the field survey data of topography and the equations of Corominas [2] and Rickenmann [7], the volume of mass movement was related to the angle of reach for each debris flow. A comparison between the Rio dos Cedros' cases and data obtained in other countries permits to conclude that the geomorphic aspects of the debris flows in Rio dos Cedros are similar to those of temperate regions.

Since there are only a few studies on debris flow hazard whose disasters in Brazil have been increasing in frequency and intensity, the present study could contribute to regional prevention measures of these disasters. The debris flows research must be more enhanced in this country, by analyzing various aspects of this hydrological hazard. In the future study, the geotechnical analysis and the vegetation analysis will have to be carried out.

\section{Acknowledgements}

The present work was supported in part by the National Research Council of Brazil (CNPq) through the Grant No. 479532/2009-5. The authors are thankful to the members of the LabHidro-UFSC for support of field survey.

\section{References}

[1] Bryant, E., Natural Hazards. Cambridge University Press: Cambridge, 2005.

[2] Corominas, J., The angle of reach as a mobility index for small and large landslides. Canadian Geotechnical Journal, 33(2), pp. 260-271, 1996.

[3] Fraga, N.C., As enchentes no Vale do Itajaí-Açu/SC: Das obras de contenção à indústria da enchente - A problemática ambiental e a relação homem/natureza na busca de soluções. Ra'EGA, 5, pp. 125-148, 2001.

[4] Frank, B. \& Pinheiro, A., (eds). Enchentes na Bacia Itajai: 20 anos de experiências. Edifurb: Blumenau, 2003.

[5] Goerl, R.F., Kobiyama, M., Lourenço, L.L. \& Grando, A., Características gerais dos escorregamentos ocorridos em novembro de 2008 nos municípios de Bruscque, Rio dos Cedros e Timbó - SC. Proc. of the XIII Simpósio Brasileiro de Geografia Física Aplicada, UFV: Viçosa, CD-rom 16 pp., 2009.

[6] Herrmann, M.L.P. (org). Atlas de Desastres Naturais do Estado de Santa Catarina. IOESC: Florianópolis, 2007.

[7] Rickenmann, D., Empirical relationships for debris flows. Natural Hazards, 19(1), pp. 47-77, 1999.

[8] Rickenmann, D., Runout Prediction Methods. Debris-flow Hazards and Related Phenomena, ed. M. Jakob \& O. Hungr, Springer: Berlin, pp. 305324, 2005.

[9] Rocha, H.L., Kobiyama, M. \& Silva, C.G., Análise estatística de chuvas intensas ocorridas nos municípios de Blumenau e Rio dos Cedros, SC, no 
88 Monitoring, Simulation, Prevention and Remediation of Dense and Debris Flows III

período de agosto de 2008 a janeiro de 2009. Proc. of the XVIII Simpósio Brasileiro de Recursos Hidricos, ABRH: Campo Grande, CD-rom 14pp., 2009.

[10] Slaymaker, O., The distinctive attributes of debris torrents. Hydrological Sciences Journal, 33(6), pp. 567-573, 1988. 